Litteratur

1. Tveråmo A, Johnsen IB, Meland E. En integrert forståelse av subjektive lidelser i klinisk praksis. Tidsskr Nor Legeforen 2014; 134: 2174-6.

2. Meland E. Vi intervjuer George. En inspirasjonskilde til humanisme i medisinen. Tidsskr Nor Lægeforen 1997; 117: 568-9.

\section{Re: En integrert forståelse av subjektive lidelser i klinisk praksis}

Objektivitetsproblemet kommer fram i debatten etter Tverråmo og medarbeideres kronikk (1). Forfatterne beskrev det velkjente misforholdet mellom objektive funn og symptomer ved noen helseplager. Dette skyldes at objektive funn hører til den biomedisinske sykdomsmodellen. Biopsykososial helhetstenkning trenger også andre måter å forstå objektivitet på. I debatten har Hofmann gjort oppmerksom på at forfatternes integrerte teori ikke bringer oss nærmere pasientens opplevelse av egen lidelse. I forfatternes siste innlegg gis Hofmann mye rett i dette. Spørsmålet er: Hvordan bør vi tenke objektivt $i$ helsetjenesten på en måte som inkluderer det subjektive? Her er tre innspill i denne debatten:

Filosofen Martin Buber påviste at ekte dialog trenger både avstand og nærhet. Avstand skapes i helsetjenesten ved at pasienten blir gjort til gjenstand for faglig kunnskap og erfaring. Dette er en form for objektivering (i kunnskapsteoretisk forstand). Men det skapes en relasjon til pasienten som et «du». Det kan oppstå en nær dialog om subjektive spørsmål (2).

Mellom 1913 og 1957 utarbeidet psykiateren og eksistensfilosofen Karl Jaspers syv utgaver av psykiatriens vitenskapsfilosofiske hovedverk: Allgemeine Psychopathologie. Hans objektivitetsbegrep favner tre perspektiver: a) det fenomenologiske, som anerkjenner subjektiv opplevelse og mål, b) det faglige, som handler om det som kan beskrives, utforskes og lages nyttige teoretiseringer om mht sykdomsprosesser og behandling, c) det kontekstuelle: forståelse mellom pasient og behandler for den aktuelle situasjons formål og mening (3).

I norsk trygdemedisinsk fagdebatt er det påvist en økende anerkjennelse av pasientens subjektive opplevelse fra 1950 til vår tid (4). Debatten gir grunnlag for å tolke inn et nytt kriterium på objektivitet i medisinsk praksis. Det erstatter ofte objektive funn. Kriteriet er «faglig beskrivelse og vurdering av pasientens opplevelse, kropp og omgivelser». Det uttrykker det jeg betegner som et holistisk objektivitetsbegrep: et begrep som anerkjenner det subjektive, det objektive og det som er vevet sammen av begge deler (i ontologisk forstand) (4).

Det finnes altså praktisk baserte muligheter for å tenke objektivitet på nye måter, og som til og med anerkjenner og gir rom for det pasienten opplever av «smerte, fortvilelse, skam og svikt» (Hofmann). Det er et objektivitetsbegrep som forøvrig ligger nær opp til upartiskhet (4).

\section{Hans Magnus Solli}

hmsolli@online.no

Hans Magnus Solli (f. 1948) er trygdemedisinsk forsker ved Klinikk psykisk helse og rusbehandling, Sykehuset i Vestfold

Ingen oppgitte interessekonflikter.

Litteratur

. Tveråmo A, Johnsen IB, Meland E. En integrert forståelse av subjektive lidelser i klinisk praksis. Tidsskr Nor Legeforen 2014; 134: 2174-6.

Buber M. Distance and Relation. I: Buber M. The Knowledge of Man. Atlantic Highlands, NJ: Humanities Press International, 1988: 49-61.

3. Jaspers K. General Psychopathology. Vol 1. Baltimore: The John Hopkins University Press, 1997.

4. Solli HM. Rettferdighet og objektivitet i trygdemedisinske uførhetsvurderinger Doktorgradsavhandling. Oslo: Universitetet i Oslo, 2007, 387-403.

\section{Re: En integrert forståelse av subjektive lidelser $\mathrm{i}$ klinisk praksis}

I Tveråmo og medarbeideres kronikk i Tidsskriftet nr. 22/2014 presenteres en modell for subjektive lidelser med relevans også fra den kliniske psykologens ståsted (1). Jeg fester meg i denne forbindelse ved begrepet «lidelse». Vår måte å forholde oss til, forstå og mestre tilstander av lidelse kan bringes inn i en videre eksistensiell og sosiokulturell kontekst.

Eksistensielt betraktet er lidelse en uunngåelig del av å være menneske. Vi ønsker alltid mer enn vi oppnår, vi lider tap, både av relasjoner, livsmuligheter og etter hvert kroppslig fungering og helse. I vår tids konsumkultur er dette underkommunisert. I denne kulturen ligger et implisitt løfte om at forbruk, bekreftelse og anerkjennelse skal heve oss opp over lidelsen. Dette skaper ikke bare nye typer av ytre krav, slik som vi ser i arbeidslivets økende krav til endringstilpasning og de sosiale medienes krav om markedsføring av selvet (2) - vi får også en ny type indre strenghet. Særlig yngre årskull rammes av indre krav om å fremstå som «enestående», eller om ikke annet, være over gjennomsnittet både med hensyn til kropp og kreativitet. Dette beskrives også som en «narsissismeepidemi» (3): Narsissistiske trekk synes å tilta, samtidig som en større del av befolkningen blir deprimerte enn tidligere når de får urealistiske forventninger og krav til seg selv om hvordan livet skal være. Behov for tilhørighet og restitusjon nedprioriteres på bekostning av mellommenneskelig konkurranse og driv etter belønning gjennom en «konkurrerende sosial mentalitet»(4). Denne disponerer i seg selv for kroppslig stress og depresjon.

Den sosiokulturelle konteksten rundt forholdet til menneskelig lidelse trenger et større drøftingsrom. De samfunnsmessige utviklingstrekkene er ikke entydig bare problematiske, og det finnes parallelt alternativer. Kjernen i den ikke-kommersielle versjonen av mindfulness, er å kunne være nærværende med det som er i livet. Dette innebærer med nødvendighet også å forholde seg til lidelse. En prøver å møte lidelse, både egen og andres, med nærvær, vennlig oppmerksomhet og anerkjennelse (5). Dette er en motsats til at psykisk smerte kapsles inn som noe skamfullt og tegn på mislykkethet. I psykoterapi er selvmedfølelse en vesentlig målsetting; å kunne behandle seg selv med vennlighet ved nederlag og tap, og å se det allmennmenneskelige ved det smertefulle. Modellen for subjektive lidelser trenger perspektiv på den sosiokulturelle konteksten med rom for mer omfattende samtidsdiagnose, og da også et bredere repertoar for lidelsens mulige mestringsveier.

\section{Per-Einar Binder}

per.binder@psykp.uib.no

Per-Einar Binder (f. 1967) er professor ved Institutt for klinisk psykologi, Universitetet i Bergen.

Ingen oppgitte interessekonflikter.

\section{Litteratur}

1. Tveråmo A, Johnsen IB, Meland E. En integrert forståelse av subjektive lidelser i klinisk praksis. Tidsskr Nor Legeforen 2014; 134: 2174-6.

2. Bauman Z. Consuming Life. Cambridge: Polity Press, 2007.

3. Twenge JM, Keith Campbell W. The Narcissism Epidemic: Living in the Age of Entitlement. New York: Free Press, 2009.

4. Liotti G, Gilbert P. Mentalizing, motivation, and social mentalities: theoretical considerations and implications for psychotherapy. Psychol Psychother 2011 84: 9-25, discussion 98-110.

5. Binder P-E. Den som vil godt. Om medfølelsens psykologi. Bergen: Fagbokforlaget, 2014 